\title{
Comparison of three non-linear models for describing Japanese quail growth curve*
}

\author{
M. Sezer ${ }^{1}$ and S. Tarhan ${ }^{2}$ \\ Gaziosmanpasa University, Faculty of Agriculture, \\ ${ }^{1}$ Department of Animal Science, \\ ${ }^{2}$ Department of Agricultural Engineering \\ Tokat 60240, Turkey
}

(Received 22 October 2004; revised version 18 February 2005; accepted 18 March 2005)

\begin{abstract}
This study has focused on the comparison of Richards, Gompertz and Logistic growth models (functions) for describing the growth characteristics of three meat-type lines of Japanese quail. The live body weight data of wild-type, doted-white and extended-brown quail lines over time were collected and fitted to the three non-linear equations. The prediction performance of the models was evaluated by statistical error tests: mean percentage error (MPE), mean bias error (MBE), root mean square error (RMSE), and confidence interval test (CIT) using the data of three out bred lines of Japanese quails (dotted white, extended brown and wild in plumage colour). The prediction performance of the growth functions for the quail growth curves depends on the line and sex of quails as shown by the results of statistical error tests. In general, Richards function predicted the weight of quails better than other two growth functions. Commonly used statistical error tests (MPE, MBE and RMSE) may not reflect the prediction performance of growth models as accurately as confidence interval test. Confidence interval tests generated likeness percentage values between 82.35 and $100 \%$ for Richards growth function.
\end{abstract}

KEYWORDS: quail, growth functions, model selection, statistical error test

\section{INTRODUCTION}

Growth in biology can be described by the changes in volume, size, or shape of an organism throughout its life. These changes can be summarized by mathematical equations fitted to growth curves. Biological meanings of the model parameters provide an opportunity to develop breeding strategies by modifying

\footnotetext{
* Supported by the Scientific Research Project Committee of GOP University, Tokat, Grant No. 2001/41

${ }^{1}$ Corresponding author: e-mail: msezer@gop.edu.tr
} 
either management practices or genetic makeup of the shape of growth curves (Aggrey, 2002, 2003). Additionally, these functions allow for the study of differences between the lines that have diverse genetic background or different feeding regimes. S-shaped or sigmoid growth curves are used to describe animal growth data. Logistic and Gompertz growth functions have been extensively used to describe growth curves of poultry. These two models have three parameters to describe growth structure and are special cases of four-parameter Richards model. Richards model has a variable inflection point determined by the shape parameter $(m)$. Logistic $(m=1)$ and Gompertz $(m=0)$ functions have a fixed point of inflection at about 50 and $37 \%$ of the asymptote, respectively.

Most of the models applied to poultry data give over $99 \%$ coefficients of determination restricting its use as a quantitative way of choosing the best model. Standard deviation (Anthony et al., 1986) and sum of square of the residuals (France et al., 1996; Akbas and Oguz, 1998; Narushin and Takma, 2003) were used in biological data for the goodness of fit of a model to different data sets or different models to a data set. On the other hand, prediction performance of the models can be quantified by additional statistical error tests (Ertekin and Yaldiz, 2000; Bermejo et al., 2003) such as mean bias error (MBE), mean percentage error (MPE), and root mean square error (RMSE). Modified statistical approach proposed by Mitchell (1997) for empirical validation of models can also be used to compare either different models or parameter values of a model for different groups of animals (Sezer and Tarhan, 2005).

The objective of this study was to determine the goodness of fit for three nonlinear functions (Richards, Gompertz, and Logistic) for describing the growth characteristics of three out-bred meat-type lines of Japanese quail (dotted white, extended brown and wild in plumage colour). Mean percentage error (MPE), mean bias error (MBE), root mean square error (RMSE), and confidence interval test (CIT) were used to compare the goodness of fit for the studied models.

\section{MATERIAL AND METHODS}

The growth data were obtained from the experiment conducted at the Gaziosmanpasa University Quail Breeding Unit. In this study, three out-bred lines of Japanese quail were used. All the birds were initially collected among the hatchling from commercial hatcheries. One of the lines was commercial meat-type Japanese quail (wild-type in colour). The other two lines were initiated by crossing wild-type line, and then selected as the extended brown and dotted white quails. The dotted white mutant shows white plumage with a small coloured spot on the head and/or back and an autosomal recessive gene controls this plumage colour 
(Tsudzuki et al., 1992). Extended brown is incompletely dominant to wild type. Homozygous brown individuals have uniformly dark brown plumage, with a small area of white feathers around the beak (Truax, 1979; Cheng and Kimura, 1990). The lines hereafter are referred as wild, white, and brown. Before the study was started, lines were maintained as folks constituted of 60 females and 20 males and reared at this unit with random-bred mating.

When the chickens hatched they were weighted and labelled with wing-rings and placed in quail battery brooders randomly. Each battery of the brooders were divided into three parts with stainless steel wire mesh and 10 birds form each line were placed in these parts randomly. Eight groups were formed for each line. Rearing conditions were identical for all the groups. Birds were weighted at 3day intervals form hatching (day 0 ) to 48 days of age with a $0.01 \mathrm{~g}$ sensitivity electronic balance. Records from quails that died before 48 days of age were not considered for modelling. The temperature started at $36^{\circ} \mathrm{C}$ and every week temperature was decreased $3{ }^{\circ} \mathrm{C}$ and fixed at $24^{\circ} \mathrm{C}$ after four weeks of age. Birds were housed for the first three weeks at $24 \mathrm{~h}$ lighting, following weeks at 16:8 light:dark cycle. Birds were allowed to ad libitum access to feed and water. They were fed with $24 \%$ crude protein (CP) and $3200 \mathrm{kcal} \mathrm{ME} / \mathrm{kg}$ starter diet for 21 days, $19 \% \mathrm{CP}$ and $3000 \mathrm{kcal} \mathrm{ME} / \mathrm{kg}$ grower diet between 21 and 35 days of age and thereafter $17 \% \mathrm{CP}$ and $2750 \mathrm{kcal} \mathrm{ME} / \mathrm{kg}$ breeder diet.

\section{Models}

Functions used in this study to describe the growth pattern of the quail were as follows:

$$
\begin{array}{ll}
\text { Richards } & W_{t}=\frac{\mathrm{W}_{0} \cdot \mathrm{W}_{\mathrm{f}}}{\left[\mathrm{W}_{0}^{\mathrm{m}}+\left(\mathrm{W}_{\mathrm{f}}^{\mathrm{m}}-\mathrm{W}_{0}^{\mathrm{m}}\right) \cdot \mathrm{e}^{-\mathrm{k} \cdot \mathrm{t}}\right]^{1 / m}} \\
\text { Logistic } & W_{t}=\frac{\mathrm{W}_{0} \cdot \mathrm{W}_{\mathrm{f}}}{\mathrm{W}_{0}+\left(\mathrm{W}_{\mathrm{f}}-\mathrm{W}_{0}\right) \cdot \mathrm{e}^{-\mathrm{k} \cdot \mathrm{t}}} \\
\text { Gompertz } & \mathrm{W}_{\mathrm{t}}=\mathrm{W}_{0} \cdot \exp \left[\mathrm{L} \cdot \frac{\left(1-\mathrm{e}^{-\mathrm{k} \cdot \mathrm{t}}\right)}{\mathrm{k}}\right]
\end{array}
$$

Where $\mathrm{W}_{\mathrm{t}}$ is body weight (BW) of bird at age $\mathrm{t}$ (grams); $\mathrm{W}_{0}$ is predicted body weight at hatching (day 0) (grams); $\mathrm{W}_{\mathrm{f}}$ is predicted final weight or asymptotic weight (grams); $\mathrm{m}$ is shape parameter, $\mathrm{k}$ is maturation index and $\mathrm{L}$ is instantaneous growth rate. The parameters were numerically estimated by the use of MarquardtLevenberg algorithm. 
Body weight data were classified into groups in terms of sex and line. Each function was fitted to the experimental data belonging to each group (not for each bird at a time). Then, weight $\left(\mathrm{W}_{\mathrm{i}}\right)$ and age $\left(\mathrm{T}_{\mathrm{i}}\right)$ at the inflection point were calculated using estimated parameters of the corresponding functions as follows:

$$
\begin{aligned}
& \text { Richards } \quad W_{i}=\frac{W_{f}}{\sqrt[m]{m+1}} \\
& T_{i}=\frac{1}{k} \cdot \ln \left|\frac{m}{\left(W_{f}^{m}-W_{0}^{m}\right) / W_{0}^{m}}\right| \\
& \text { Logistic } \quad W_{i}=\frac{W_{f}}{2} \\
& T_{i}=\frac{1}{k} \cdot \ln \left(\frac{W_{f}-W_{0}}{W_{0}}\right) \\
& \text { Gompertz } \quad W_{i}=\frac{W_{f}}{e} \\
& \mathrm{~W}_{\mathrm{f}}=\mathrm{W}_{0} \cdot \mathrm{e}^{\mathrm{L} / \mathrm{k}} \\
& T_{i}=\frac{1}{k} \cdot \ln \left(\frac{L}{k}\right)
\end{aligned}
$$

\section{Criteria}

The goodness of the models was evaluated by the following statistical error test (Ertekin and Yaldiz, 2000):

Mean bias error (MBE)

$$
\begin{aligned}
& =\sum_{i=1}^{n} \frac{H_{i, c}-H_{i, a}}{n} \\
& =\sum_{i=1}^{n} \frac{\left[\left(H_{i, c}-H_{i, a}\right) / H_{i, a}\right] \cdot 100}{n}
\end{aligned}
$$

Mean percentage error (MPE)

$$
=\left(\frac{\sum_{i=1}^{n}\left(H_{i, c}-H_{i, a}\right)^{2}}{n}\right)^{1 / 2}
$$

where $\mathrm{H}_{\mathrm{i}, \mathrm{a}}$ is the $i$ th measured value, $\mathrm{H}_{\mathrm{i}, \mathrm{c}}$ is the $i$ th calculated value and $\mathrm{n}$ is the total number of observations.

Standard deviation of the residuals utilise the MBE as a correction factor. Hence it can lead lower estimation of the deviation between predicted and observed values than the one estimated by RMSE that allows comparison of 
the actual deviation between predicted and observed values without considering average of differences. Furthermore, The RMSE test gives the information on the short-term performance of the model by allowing a term by term comparison of the actual deviation between estimated and measured values. Low values of MBE and MPE are desired and their positive or negative values give the average amount and percentage of the over or under estimation of the models, respectively. The values of the MBE represent the systematic error or bias, while the RMSE is a non-systematic error (Onier, 1994). Although these statistical error tests can be reliable ways of choosing the best model among a number of growth functions (Rehman, 1999), sensitivity to extreme values in observed data, neutralization of over and lower estimations and lack of flexibility in comparing different data sets and limit their use as decisive factors.

Confidence interval test considers the number of predictions staying within the 95\% confidence intervals of experimental data collected at each sampling point (Sezer and Tarhan, 2005). Then, the likeliness percentage (LP) is calculated as the ratio of the number of prediction staying within the confidence interval to total number of prediction. LP values could be between 0 and 100, based on the prediction performance of the model in consideration. LP can be formulated as follows:

$$
\text { Mean bias error (MBE) }=\frac{\mathrm{s}}{\mathrm{n}} \times 100
$$

where $\mathrm{s}$ is the number of predictions staying within the confidence intervals and $\mathrm{n}$ is the number of sampling points for each line. It is generally impossible to get the $100 \mathrm{LP}$ values in practice. So, it is logical to choice a tolerance limit such as 5 or $10 \%$ to decide whether a model adequate to describe a data set.

\section{RESULTS}

The values and standard errors of the function parameters and age and weight at the inflection point were presented in Table 1. In this study, measured hatchling weights of the lines over sex were between 8.45 and 8.97. Hatchling weights were estimated higher for Logistic and lower for Gompertz function than that for Richards function. The occurrence of differences between predicted and measured hatchling weights by the Gompertz and logistic models were reported in literature (Mignon-Grasteau et al., 1999; Aggrey, 2002).

Maturation index were estimated high for males and low for females by the three models. Consequently, males reached to the maximum growth sooner than females (low time of inflection point). Estimated maturation indexes were 


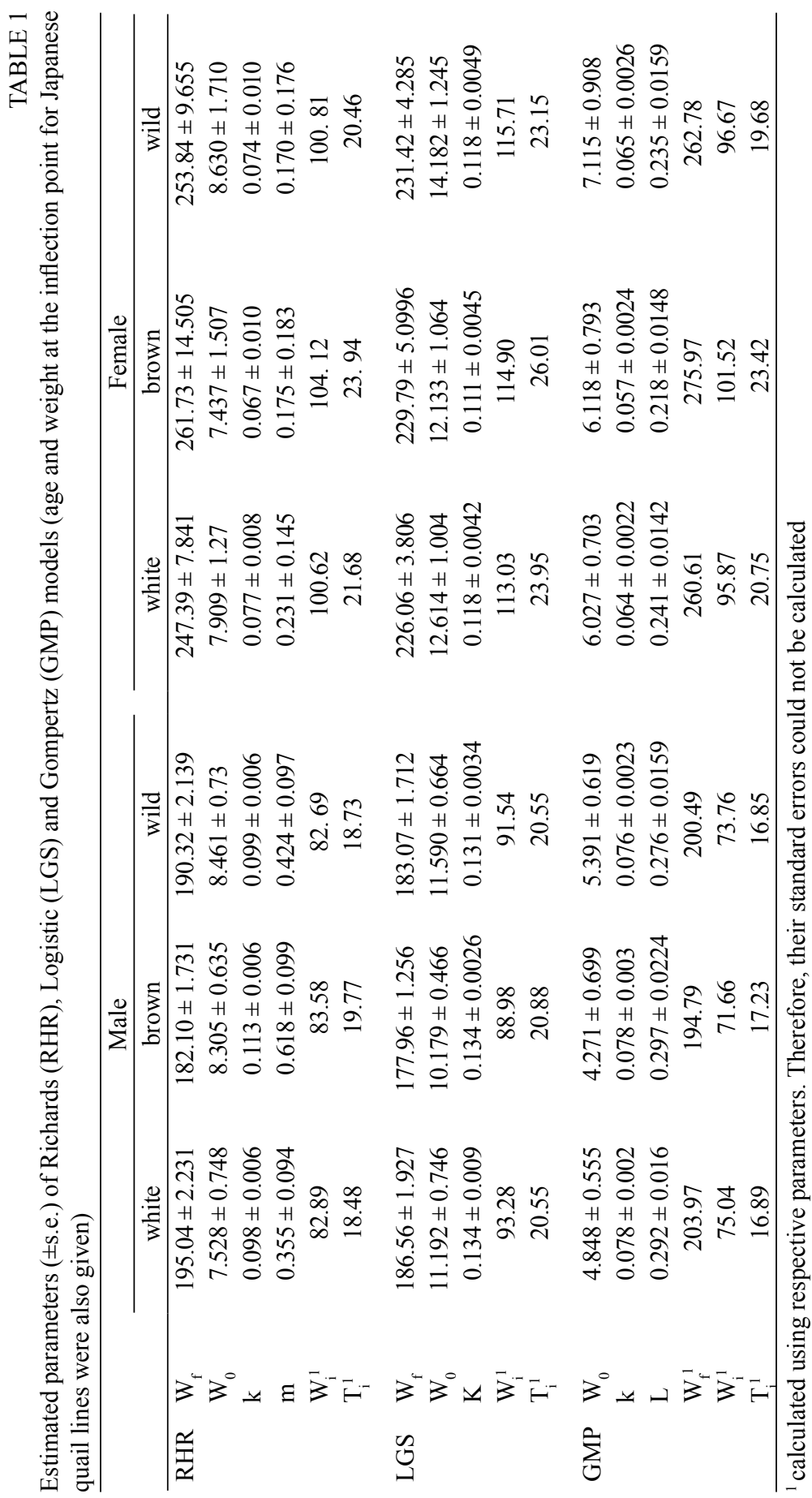


similar to the previous reports (Hyankova et al., 1997; Akbas and Oguz, 1998). Instantaneous growth rates (the parameter L for Gompertz model) were estimated high for males and low for females.

When the Richards model was used to describe the growth curve, the $\mathrm{W}_{\mathrm{i}} / \mathrm{W}_{\mathrm{f}}$ ratio is preferred to $\mathrm{m}$ parameter to compare the shape of the growth curve of different sex or lines (Hyankova et al., 1997, 2001). Logistic and Gompertz functions have a fixed point of inflection at about 50 and $37 \%$ of the asymptote, respectively (Aggrey, 2002). The $\mathrm{W}_{\mathrm{i}} / \mathrm{W}_{\mathrm{f}}$ ratios were between 45.90 and $43.45 \%$ for males, 40.67 and $39.71 \%$ for females of the lines. These values are consistent with the previous reports indicating that males of Japanese quail have higher $\mathrm{W}_{\mathrm{i}} / \mathrm{W}_{\mathrm{f}}$ ratio than females have. Female of the brown line has the highest asymptotic weight $\left(\mathrm{W}_{\mathrm{f}}\right)$ estimated by Gompertz and Richards models. The duration of the experimental period could be short and lead to over estimation of the asymptotic weight especially for the slow growing lines.

Comparison criteria of the functions were presented in Tables 2 and 3. Three models in consideration explained over $99.86 \%$ of variation in liveweight data for Japanese quail lines. Calculated MPE (\%) and MBE (g) were positive for logistic and negative for Gompertz and near to zero for Richards model. This could be expected because of the fixed inflection points due to fixed shape parameters for the Gompertz and logistic models. Gompertz growth curve shows faster early growth, but slower approach to asymptote and longer linear period about the inflection point than the logistic one (France and Thornley, 1984). Richards function eliminates over or lower estimations arising from shape of the curves. Similarly, most of the RMSE's (g) were calculated higher for logistic and lower for Richards models indicating the best fit of the Richards function to the data. It has been reported that Gompertz model gave the best fit for poultry data among the three-parameter models (Anthony et al., 1986, 1991; Akbas and Oguz, 1998). As it is expected, four-parameter Richards model gave better fit than the three-parameter models. The extra parameter $m$ of Richards function has a biological meaning and usable in physiological studies (Aggrey, 2002). Hence Richards model has an advantage over the other models.

Comparison of the LP values for the models also shows that Richards function is the best one among three models to describe the growth characteristics of quail lines except brown female. RMSE, MBE, and MPE did not separately account the experimental errors associated with the measured data. Therefore, all errors were treated as a result of model insufficiency. On the other hand, LP treated separately experimental errors and prediction errors. Furthermore, RMSE, MBE, and MPE are unit dependent. As a result, confidence interval test gives a chance to compare the fitting goodness of a model to different data sets. In addition, LP values belonging to the modelling results of different quail 


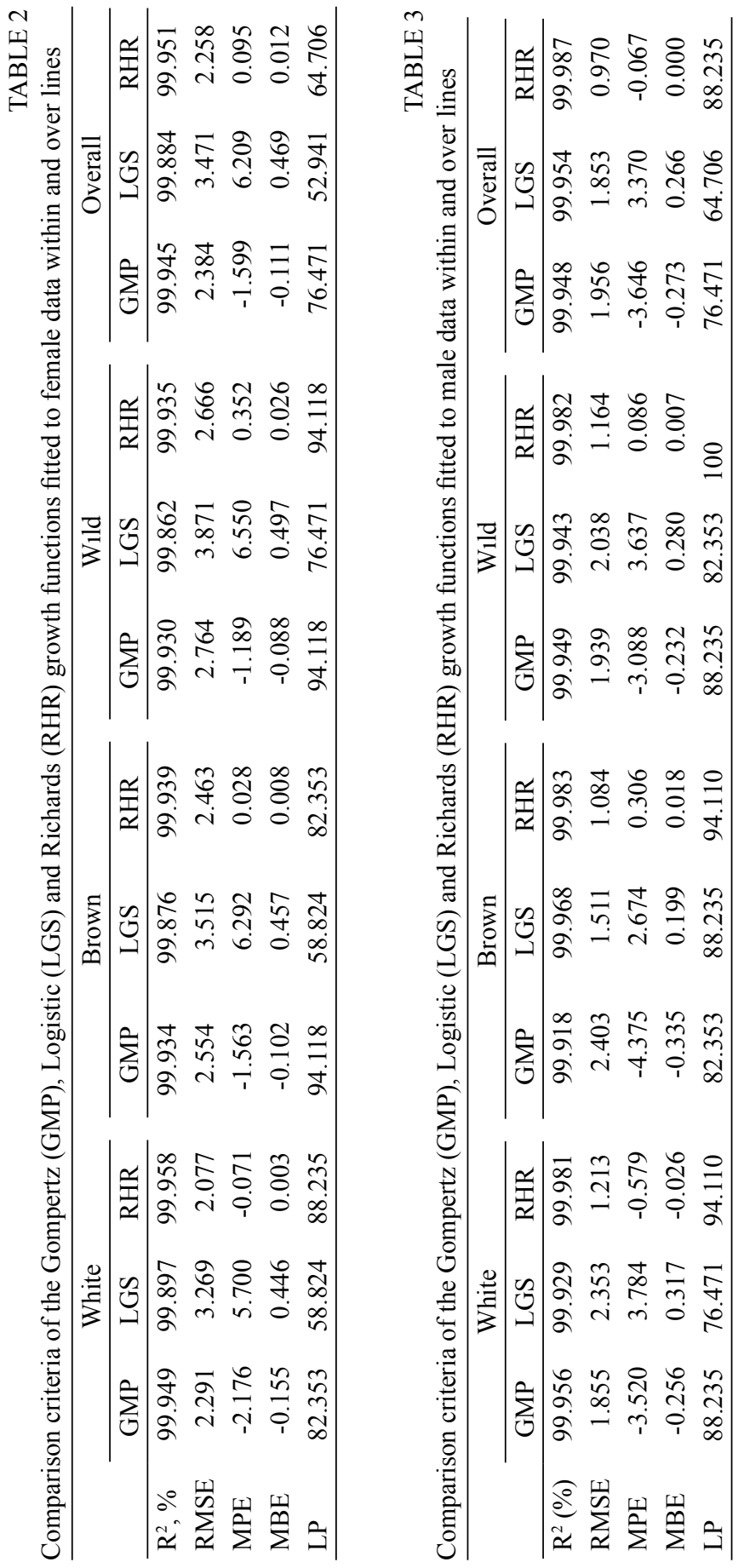


lines are comparable with each other. While Richards model had the lower values of RMSE and MBE for female white line than those for female wild line, LP value was higher for female wild line than for female white line. As a result, the common statistical error tests were insufficient for comparing the goodness of fit.

\section{CONCLUSIONS}

The prediction performance of the growth functions for the quail growth curves depends on the type and sex of quails. In general, Richardson function predicted the weight of quails better than other two growth functions. However, Gompertz function was found to be the best for the female brown quails, probably because of their longer biological age. Therefore, Gompertz function may be able to predict the growth data belonging to the quails that did not complete the development period during experimentation. The order of the models based on the best fit was Richards, Gompertz and Logistic. On the other hand, confidence interval test gives a chance to compare the fitting goodness of a model to different animal groups.

\section{REFERENCES}

Aggrey S.E., 2002. Comparison of three nonlinear and spline regression models for describing chicken growth curves. Poultry Sci. 81, 1782-1788

Aggrey S.E., 2003. Dynamics of relative growth rate in Japanese quail lines divergently selected for growth and their control. Growth, Develop. Aging 67, 47-54

Akbas Y., Oguz İ., 1998. Growth curve parameters of lines of Japanese quail (Coturnix coturnix japonica), Unselected and selected for four-week body weight. Arch. Geflügelk. 62, 104-109

Anthony N.B., Nestor K.E., Bacon W.L., 1986. Growth curves of Japanese quail as modified by divergent selection for 4-week body weight. Poultry Sci. 65, 1825-1833

Anthony N.B., Nestor K.E., Marks H.L., 1996. Short-term selection for four-week body weight in Japanese quail. Poultry Sci. 75, 1192-1197

Bermejo J.L., Roehe R., Rave G., Kalm E., 2003. Comparison of linear and nonlinear functions and covariance structures to estimate feed intake pattern in growing pigs. Livest. Prod. Sci. 82, 15-26

Ertekin C., Yaldiz O., 2000. Comparison of some existing models for estimating global solar radiation for Antalya (Turkey). Energ. Conv. Manage. 41, 311-330

France J., Dijkstra J., Dhanoa M.S., 1996. Growth functions and their application in animal science. Ann. Zootech. 45, Suppl., 165-174

France J., Thornley J.H.M., 1984. Mathematical Models in Agriculture. Butterworth and Co. Ltd., London

Hyankova L., Dedkova L., Knizetova H., Klecker D., 1997. Responses in growth, food intake and food conversion efficiency to different dietary protein concentrations in meat-type lines of Japanese quail. Brit. Poultry Sci. 38, 564-570 
Hyankova L., Knizetova H., Dedkova L., Hort J., 2001. Divergent selection for shape of growth curve in Japanese quail. 1. Responses in growth parameters and food conversion. Brit. Poultry Sci. 42, 583-589

Mignon-Grasteau S., Beaumont C., LeeBihan-Duval E., Poivey J.P., de Rochambeau H., Richard F.H., 1999. Genetic parameters of growth curve parameters in male and female chickens. Brit. Poultry Sci. 40, 44-51

Mitchell P.L., 1997. Misuse of regression for empirical validation of models. Agr. Syst. 54, 313-326

Narushin V.G., Takma C., 2003. Sigmoid model for the evaluation of growth and production curves in laying hens. Biosyst. Engin. 84, 343-348

Onier A.M., 1994. Diffuse solar radiation over Shambat, Khartoum North. Renew. Energy 4, 227-233

Rehman S., 1999. Empirical model development and comparison with existing correlations. Appl. Energ. 64, 369-378

Sezer M., Tarhan S., 2005. Model parameters of growth curves of three meat-type lines of Japanese quail. Czech. J. Anim. Sci. 50, 22-30

\section{STRESZCZENIE}

\section{Porównanie trzech modeli nieliniowych do opisu krzywych wzrostu przepiórki japońskiej}

Celem badań było porównanie dopasowania modeli Richarda, Gompertza i logistycznego do opisu krzywych wzrostu trzech mięsnych linii przepiórek. Analizowano pomiary przyżyciowej masy ciała (i jej zmian w czasie) dzikiej, białej cętkowanej i brązowej linii przepiórek i ich dopasowania do trzech nieliniowych modeli. Oceny możliwości predykcyjnych tych modeli dokonano przy pomocy następujących kryteriów statystycznych: średni procent błędu (MPE), średnie obciążenie (MBE), średni kwadrat błędu (RMSE) oraz przedział ufności (CIT). Na podstawie wyżej wymienionych kryteriów stwierdzono, że możliwości predykcyjne funkcji wzrostu dla przepiórek zależą od linii i płci przepiórek. Generalnie, predykcja masy ciała przepiórek na podstawie funkcji Richardsa była lepsza niż uzyskana z dwóch pozostałych funkcji wzrostu. Stwierdzono ponadto, że ocena zdolności predykcyjnych modeli krzywych wzrostu jest lepsza na podstawie przedziałów ufności aniżeli kryteriów opierających się na tzw. testach błędów statystycznych. Należy podkreślić, że dla krzywej Richardsa procent podobieństwa, definiowany jako liczba przewidywanych wartości mieszczących się $\mathrm{w}$ przedziale ufności do ogólnej liczby predyktorów, mieścił się między 82,35 a 100\%. 